\title{
An Overview of Continuity of Care Model for Children With Juvenile Diabetes in West Java Region, Indonesia
}

\author{
Hotma Rumahorbo $^{1}$, Atin Karjatin ${ }^{1} \&$ Lia Herliana ${ }^{2}$ \\ ${ }^{1}$ Health Polytechnic of the Ministry of Health, Bandung, West Java, Indonesia \\ ${ }^{2}$ Health Polytechnic of the Ministry of Health, Tasikmalaya, West Java, Indonesia \\ Correspondence: Hotma Rumahorbo, Health Polytechnic of the Ministry of Health, Bandung, Dr. Otten 32 \\ Bandung, West Java, Indonesia. E-mail: hotma_rumahorbo@yahoo.com
}

Received: May 10, 2019 Accepted: June 18, 2019 Online Published: July 1, 2019

doi:10.5539/gjhs.v11n9p46

URL: https://doi.org/10.5539/gjhs.v11n9p46

\begin{abstract}
Introduction: The absence of insulin in people with Juvenile Diabetes (JD) requires that they get daily injections of insulin in addition to daily lifestyle that must be managed. Children with JD requires routine care and check-ups from doctors and nurses in hospitals so that the quality of life of children can be optimal. This researchaimed to obtain an overview of JD continuityof care model.
\end{abstract}

Method: The design implementedwas descriptive phenomenology. The number of participantswas 18 people, consisting of 6 JD patients: 3 parents, 2 guidance and counseling teachers, 2 doctors, 1 midwife and 3 nurses. The data were analyzed using Collaizi method.

Results: This research identified 8 themesi. e1) health education from doctors and nurses is needed regularly; 2) the treating doctor does not change frequently because it will be confusing; 3) looking for treatment because of responsibility and feeling sad for children; 4) insulin medicine is obtained according to what the doctor programmed; 5) simplified registration system; 6) fast service; 7) the teacher knows how to supervise children in school and 8) the parents need a community as means of sharing information.

Conclusions: Continuity of care model for JD is related to 3 aspectsof service, i.e.continuity of information; communicationcontinuity and continuity of management to becontained in the INKOLA Model (Informasi, Komunikasi and Tata Kelola). The result of research are expected to give information about the need of care so that a proper continuity of care model can be develop.

Keywords: children, diabetes mellitus, nurses, quality of life

\section{Introduction}

Diabetes Mellitus is a syndrome of metabolism disorder characterized by hyperglycemia as a result of insulin secretion deficiency or a decrease of biological activity of insulin or both of them (Abolfotouh, Kamal, El-Bourgy, $\&$ Mohamed, 2011). Diabetes is a serious health problem faced by many countries. Nowadays, Indonesiais ranked fourth in diabetes after United States of America, China and India. Juvenile Diabetes (JD) is a type 1 diabetes or Insulin Dependent Diabetes Mellitus (IDDM) occurring in children. It is hereditary and caused by autoimmune reaction in beta pancreas cells (Abolfotouh, Kamal, El-Bourgy, \& Mohamed, 2011). Children with JD need insulin injection, diet management and physical exercise as well as emotional conditions that have to be maintained (Abolfotouh, Kamal, El-Bourgy, \& Mohamed, 2011) so thatglucose in blood remains balanced and they are prevented from acute complication threat. Acute complications such ashypoglycemia and diabetic ketoacidosis are the biggest threat for children with JD (ADA, 2005). Besides that, the occurrence of chronic complications such as coronary heart, hypertension, stroke, neuron disorder, kidney failure, blindness (Association, n.d.) are also the threat for children with JD. Impact of the disease is not only towards organ damage but also affectingsocial-psychological condition. The prevalence of psychiatric disordersoccurringin people with diabetes are anxiety (20\%), withdrawing (7\%), depression (5.5\%) and prolonged depression (3.5\%) as well as suicide risk (2\%). From all cases, $42.5 \%$ suffer frommore than one psychiatric disorders (Boulton, 2004). Children with diabetes havetwice higher prevalence of depression, and for adolescents, three times higherthan those without diabetes (Kesehatan, 2014). Depression on children and adolescents correlated with bad health condition, blood glucose and recurrence of ketoacidosis complication (Brunilda, 2009). Centre for Disease Control and Prevention 
(CDC, 2014) states that children with JD need special treatment (Cheng, Chen, \& Hou, 2010), especially if the children with JD are still in school. The special treatment is focused on continuity care related to daily insulin injection, diet and balanced physical exercise, routine medical checkup, emotional balance and optimal stress management.

Continuous treatment of children with JD is a process where children with JD and health officers particularly nurse and/or doctors work together in managing health care of JD sufferers so that they receive optimal living quality and efficient health cost (Hood, Huestis, Maher, Butler, \& Volkening, 2006) living quality of children with JD is very critical in supporting optimization of their roles as productive family members either in school or in their families so their goals, expectations and wills could be achieved. In developed countries, some treatment models of chronic disease patients have been developed and used for Diabetes sufferers: 1) Promoter model or Community health worker (CHW) model, a model built from the existence of trained community members who is in charge to reach community and deliver messages about prevention and health promotion; 2) Chronic Disease Care Model. The development of this model is encouraged by awareness and different needs in patients with acute and chronic diseases. With this model, patients with chronic disease would be proactive in interacting with the health team in building the ability of self-management so they could change their habitstobecome activities that can improve their health qualities; 3) Coalition Model, this model is used in empowering people with diabetes which is emphasized in the collaboration of several organizations in the community, supporting each other and becoming an important part in building patients' health; 4) Continuous Care Model. This model has been reviewed for so many times in developed countries. Freeman and Huges (2010) define continuous care according to relationship dimension and case management dimension (Maia, Braga Ade, Brouwers, \& Nardi, n.d.). Meanwhile, Ontario addsrelational continuity between patients and health officers (Murillo et al., 2017).

In Indonesia, the continuity of care model for children with JD has not been met. Rumahorbo (2012) develops SESAMA model in helping prediabetes patients to manage their diet pattern and physical exercise so they are prevented from diabetes. This model synergizes nurses in community health center, health cadres and people with prediabetes in managing their lifestyle so that the balance of blood glucose is optimal (Lee, Huxley, Lam, Martiniuk, Ueshema, \& Pan, 2005). WHO (2002) in The Innovative Care for Chronic Condition (ICCC) framework states that continuous care quality for people with chronic disease involves patients and their families, community, health team and policy makers(Huges, 2010). In the level of executor, the collaboration between patients and their families, community and health team could be maintained well through good preparation, motivation, information and commitment to work together. Cooperation also needs to be supported by health service organizations and community organizations that can give optimal conditionfor the continuity of cooperation. The use of ICCC Framework model is effective to improve life quality of patients (Huges, 2010), decreasehealth cost and improve several factors in patients' empowerment (Huges, 2010) and to decrease weight of obese patients and give positive impact toward the treatment of people with diabetes. Family as an inseparable part ofthe lives of children with JD becomes an important part in giving treatment and teaching and presenting supportive environment to support the children's health condition (InfoDATIN, n.d.). Education interventions can increase family contribution in handling children with JD (Nouwen, Neps, Caramlau, Connock, Winkley, Lloyd, \& Peyrot, 2011). Family conflict related to diabetes in children is a string predictor toward children with JD life quality (Ontario, 2010; Rumahorbo Hotma, 2013)

\section{Materials and Methods}

The approaches used in this research were phenomenology and literature review. The participants of this research were children with Juvenile Diabetes, parents of children with JD, teachers, doctors and prolanis program holder. Data collection was conducted through literature review, in-depth interview and FGD. Literature review was aimed to review various similar models that have been developed in Indonesia or other countries. The models obtained would be tested for their management ability in the field through deep interview with informants and focus group discussion. The data collected during research werethe result of in-depth interview and the result of observation, which was field note. Data analysis in this research was thematic analysis using Colaizzi (1978 in Streubert \& Carpenter, 2003) approach.

\section{Results}

The participants were 18 Respondentsof "P" (People with JD) consisting of 3 males and 3 females. The age ranged between 7-14 years old: 4 persons in Elementary School and 2 persons in Junior High School. The length of suffering from diabetes was between 1-10 years; Respondent of "OP" (Patients' Parents): all three were housewives, aged between 30-34 years old, educational background of Junior High School and Senior High School, and their head of family work in private companies; Respondents of "GS" (School Teacher): consisted of 3 
Health School teacher and guidance and counseling teacher. They all were female and knew patients for about 12 years; Respondent of "Dr" (doctors): both of them were female, handling patient in prolanis program for 6 months -2 years. Respondents of "Ns" (Nurses): Both of them were female, 1 midwife and 3nurses, handled prolanis for 6 months -3 years.

According to literature review, the result is as follows: Freeman and Huges (2010) defines continuous care according to relational dimension and case management dimension (Smeltzer \& Bare, 2007). Continuous relational dimension is called relationship continuity which means that, sustainably, patients and health officers establish therapeutic relationship. Continuous case management dimension isreferred to as management continuitywhich means that there is consistency and continuity of patients' management including provision of information, plan for nursing care, therapy program and care needs coordination. Ontario (2013) defines continuous care from 3 dimensions which consist of informational continuity, management continuity and relational continuity between patients and health officers. Informational continuity is defined as the availability of information about patients in all health service settings. The continuity of case management is defined as the availability of standard and protocol used in taking care of patients, accessibility of patients in obtaining service and the facility for patients to make an appointment with health officers. Relational continuity is defined as therapeutic relationship between patients and health officers sustainably.

According to the results of the analysis, parents of children with JD want fast services and do not want to wait longer because it is exhausting for their children, besides that they have to leave school; "manual registration, long queue, feeling pity for the children" (P1), the registration took so long, having to wait for the doctor, taking a long time to get theprescription too, children were so tired, children at least had to leave school for 2 days in a month only to check on their health; there is continuity of information about children condition from every doctor's visit so parents can learnhow their children improve; "there was doctor's phone number, but did not dare to text him" (OP1\&2), "I hadasked by SMS but the doctor did not reply, so I do not want to do that again" (P1), "receivinginformation directly from the doctor, yachhh,... understood, enough (laughing, but doubtful)" (OP1); Insulin isavailable according to children's needs; "insulin is limited, the insulin sometimes is not available in hospital so we have to find it in any BPJS drugstore, sometimes we have to buy it ourselves" (OP1); the needs and availability of adequate information from health officer and provision of informationplacewhen parents face difficult conditions in handling their children at home, "they only explained about medicines. Food was not limited, ... children could eat anything they wanted" (OP1 \& 2), "the doctors change frequently, so the information received often times different (OP1\&2), wah...I'm so happy but never do that" (OP1 \& 2): there is intimate and harmonious relationship between health officers, similarity and adequacy of information between parents and teachers and sharing information about children's condition. The arrangement of service system could ease the access to medicine and registration and also to children'scondition that is monitored and delivered to parents. Service administration should give possibilityfor children not to leave their school for too long ( $2-5$ days in a month) because they have to do blood check as a requirements to getprescriptiongiven by the doctor and also time to wait for the doctor.

\section{Discussion}

From the thematic analysis, 3 aspects related to the continuous care for children with JD are obtained:

A. Informational Continuity: Information obtained from health officers (doctors and nurses) continuously for every childwith JD; therapeutic relationship that does not only occur inside the hospital but also in the house reciprocally.

B. Communicational Continuity: to know each other, between doctors, nurses, parents of children with JD and administrative officers.

C. Management Continuity: service standard and compliance are to be implemented by all related parties and socialized with parents of children with JD; hospital has SOP to treat children with JD related to registration; service flow; laboratories check, provision of medicines and guidance toward children's need when they are in house; involvement of parents in decision making for children with JD as well school and teachers need to be involved in health care of children with JD. Children receive medicines in accordance with their treatment and laboratory examination for the need of treatment. Health officers (doctors and nurses) monitor children with JD continuously and monitor parents who are lazy in taking their children to thehospital for control.

Continuity of Careis related to "Informasi, Komunikasidan Tata Kelola," abbreviated as INKOLA. Components of INKOLA are children's families (children with JD and Parents), Hospital (System, Policy, Health Officers 
(Doctors and Nurses)and School (guidance and counseling teachers and UKS teachers).

\subsection{Model Description}

INKOLA model is a continuity model for children with Juvenile Diabetes by involving important elements related in children's life such as family, especially parents, school that is represented by guidance and counseling teachers /school health teachers andhospital by doctors and nurses as health officers whoconduct health care directly to children with JD and their families. The relationship between components in the INKOLA model is shown in the following Figure 1.

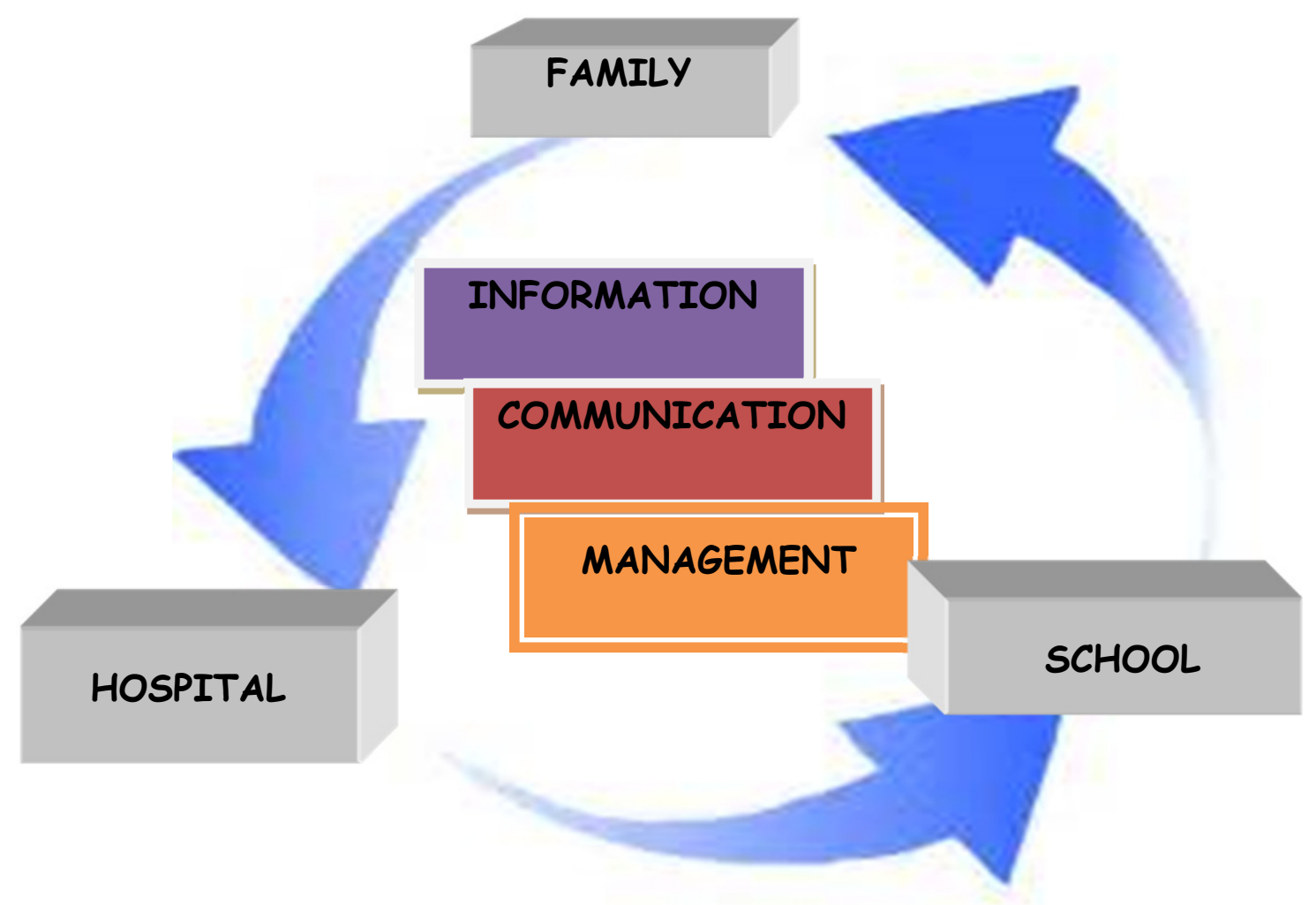

Figure 1. Shows the relationship between the three components in the INKOLA Model

The model describes the availability, adequacy and consistency of information received by patients either in hospital, house and school from all related elements so the patients can undergo their daily activities and have optimal life quality and the availability of policy and protocol to provide integrative treatments to patients continuously. Standardization of consistent electronic registration system and implementation of service policy of treatment and laboratory are needed.

\subsection{Model Components}

\section{a. Hospital}

As an institution providing health care providers and service policies that can facilitate patients in accessing services related to the registration system, laboratory services. Adequacy and ease in obtaining drugs according to the therapy program of the treating doctor. Holistic and sustainable services, supported by health workers who are relatively constant in providing services to patients so that continuity of services and information can be obtained by JD persons and their families. Good governance that allows people with Juvenile Diabetes and their families to get standardized services related to nursing care, medical services and laboratory services as well as continuous care and monitoring of children's health at home.

The hospital also needs to build partnerships with schools in building networks in providing services and assistance in schools. 
b. Family

As the closest environment for children with JD, families are a source fulfilling the physical and emotional needs of children; therefore, their involvement is important in caring for children at home. Parents and/or children are equipped with therapeutic information and communication for growth by doctors and nurses, thus providing comprehensive nursing services for patients in hospitals and at home.

c. School

School is the second institution after the family where the child spends the most time in and is active there. Schools where children learn need readiness to recognize the needs of children with diabetes. Knowledge and attitudes of teachers regarding diabetes that occurs in children and skills in managing unexpected conditions that the children might experience at school.

The INKOLA model is a model that still requires the elaboration of various programs and activities specifically in integrating elements of the family, hospitaland school in the development of meeting the ongoing care needs of information, communication and governance. Governance services in hospitals as complex elements require structuring the system of health services such as registration, health examination services, procurement of medicines, laboratory examinations, doctor assignment systems and patient nursing care. Provision of fixed protocols (Protap) services and their implementation are needed consistently.

\section{Conclusion}

The INKOLA model is a model of continuity of care for children with Juvenile diabeteswhich describes the relationship between Juvenile diabetic family, hospitals as health care institutions and schools as educational institutions.Descriptions of various programs and activities are needed in integrating the elements involved in the model so that they can be applied in improving the quality of life of children with JD.

\section{Recommendation}

Further research is needed in implementing the INKOLA intervention program to obtain optimal quality of life for children with JD. It is also necessary to optimize the role of first-level health facilities (Puskesmas) in developing sustainable care for children with JD.

\section{Competing Interests Statement}

The authors declare that there are no competing or potential conflicts of interest.

\section{References}

(ADA), A. D. A. (2005). Diagnosis and classification of diabetes mellitus. Diabetes Care, 28(1), 37-42. https://doi.org/10.2337/diacare.28.suppl_1.S37

Abolfotouh, M. A., Kamal, M. M., El-Bourgy, M. D., \& Mohamed, S. G. (2011). Quality of life and glycemic control in adolescents with type 1 diabetes and the impact of an education intervention. International Journal of General Medicine, 4, 141-152. https://doi.org/10.2147/IJGM.S16951

Association, A. D. (n.d.). Living With Type 1 Diabetes. Retrieved from http://www.diabetes.org/living-with-diabetes/recently-diagnosed/living-with-type-1-diabetes.html

Boulton. (2004). Neuropathic diabetic foot ulcers. N Eng J Med, 48-55. https://doi.org/10.1056/NEJMcp032966

Brunilda, N. M. (2009). Diabetes Complications: What's Your Risk?,WebMD Feature. Retrieved November 6, 2009, from www.fda.gov

Cheng, S. H., Chen, C. C., \& Hou, Y. F. (2010). A longitudinal examination of continuity of care and avoidable hospitalization: evidence from a universal coverage health care system. Archives of internal medicine, 170(18), 1671-1677. https://doi.org/10.1001/archinternmed.2010.340

Hood, K. K., Huestis, S., Maher, A., Butler, D., \& Volkening, L. L. L. (2006). Depressive symptoms in children and adolescents with type 1 diabetes: association with diabetes-specific characteristics. Diabetes Care, 29(6), 1389. https://doi.org/10.2337/dc06-0087

Huges, F. J. (2010). Contuinity of care and The Patient Experience. Englang: TheKingsfund.

InfoDATIN. (n.d.). Situasi dan Analisis Diabetes dalam rangka Hari Diabetes Sedunia Tahun 2014. Retrieved from http://www.depkes.go.id/resources/download/pusdatin/infodatin/infodatin-diabetes.pdf

Kesehatan, B. (2014). Panduan Praktis Program Pengelolaan Penyakit Kronis (PROLANIS). Jakarta.

Lee, C. M, Huxley, R. R, Lam, T. H, Martiniuk, A. L, Ueshema, H, Pan, W. H, et al. (2005). Prevalence of Diabetes 
Melitus and Population attributable fractions for coronary heart disease and stroke mobility in the WHO South-East Asia and Western Pacific regions. Australia: The George Institute for International Health,.

Maia, A. C., Braga Ade, A., Brouwers, A., Nardi, A. E., O. e S. A. (n.d.). Prevalence of psychiatric disorders in patients with diabetes types 1 and 2. Retrieved from http://www.ncbi.nlm.nih.gov/pubmed/22521330

Murillo, M., Bel, J., Pérez, J., Corripio, R., Carreras, G., Herrero, X., ... Rajmil, L. (2017). Health-related quality of life (HRQOL) and its associated factors in children with Type 1 Diabetes Mellitus (T1DM). BMC Pediatrics, 17(16). https://doi.org/10.1186/s12887-017-0788-x

Nouwen, A., Nefs, G., Caramlau, I., Connock, M., Winkley, K., Lloyd, C. E., ... \& European Depression in Diabetes (EDID) Research Consortium. (2011). Prevalence of depression in individuals with impaired glucose metabolism or undiagnosed diabetes: a systematic review and meta-analysis of the European Depression in Diabetes (EDID) Research Consortium. Diabetes Care, 34(3), 752-762. https://doi.org/10.2337/dc10-1414

Ontario. (2010). Contuinity of care to Optimize Chronic Disease Management in The Community Settings: An Evidence Based Analysis. Ontario Health Technology Assesment Series, 13(6), 1-41.

Rumahorbo, H. (2013). Model SESAMA, Model Pencegahan Diabetes Berbasis Masyarakat.

Smeltzer, S. C., \& Bare, B. (2007). Medical-surgical nursing (10th ed.). St Louis: Lippincott Williams \& Wilkins.

\section{Copyrights}

Copyright for this article is retained by the author(s), with first publication rights granted to the journal.

This is an open-access article distributed under the terms and conditions of the Creative Commons Attribution license (http://creativecommons.org/licenses/by/4.0/). 